\title{
超音波によるペルテス病の評価
}

\begin{tabular}{|c|c|c|c|c|c|}
\hline 鈴 & 木 & 茂 & 夫・粟 & 屋 & 梧 \\
\hline 岡 & 田 & & 温 - 池 & 田 & 俊 \\
\hline 多 & 田 & 弘 & 史 & & \\
\hline
\end{tabular}

\section{Ultrasonic Diagnosis for Legg-Calve-Perthes Disease}

by

Shigeo Suzuki, Goro Awaya, Atsushi Okada, Toshihiko Ikeda and Hiroshi Tada

Department of Orthopedic Surgery, Kokura Memorial Hospital, Kitakushu, 802 Japan

Ultrasonic examination was performed on 11 cases of Legg-Calve-Perthes disease (LCPD). The cartilaginous femoral head, the nucleus, the iliac bone and the limbus were visualized by ultrasonography. In LCPD the deformity of the cartilaginous femoral head and the fragmentation of the nucleus can be demonstrated. We developed "echo-index" which is a new method for measurement of ultrasonographic results of LCPD. The results of echo-index is well correlated with those of caput-index by Jonsäter. We presented the ultrasonographs of 4 cases of LCPD comparing the results of arthrography. Ultrasonic examination is non-invasive and we think that it is very useful for the evaluation for LCPD.

\section{はじめに}

年少児の大腿骨頭は，軟骨部分が多く，このため， ペルテス病による骨頭の経時的変化, あるいは遺残変 形を正確に評価するには，関節造影を行わなければな らない.しかし, ペルテス病の発症は，一般に10才未 満のことが多く，関節造影検査をする場合は全身麻醉 を必要とするなど，患者にとっても，検者にとっても 負担が大きいものである，もし，超音波でペルテス病 による骨頭変化が正しく評価することが可能ならば， 関節造影に伴う麻酔や，レ線被曝から解放される。

私たちは，すでに，超音波断層撮影によって先天股 脱の診断が正確に行われることを報告してきた。この たび, 超音波断層法がペルテス病の診断にも応用出来 るか否か検討を重权てきたので報告する.

\section{方法}

対象は, 1984 年 4 月から, 1985 年 9 月までに診察, 治療を行ったペルテス病 11 例である。方法は，まず，
小児を仰臥位とし，股関節をやや届曲そして最大内転 位とする．そして，大転子のやや中枢寄りにトランス ヂューサを置き，大朖骨頭の綎断面わよび横断面を screen に写してポラロイド撮影を行う。良い断面像を 得るためには，トランスヂューサをできるだけ静止さ せることが大切である。

計測方法：図 1 の左は, 縦の半径を横の半径で制る Jonsäter にしたがって Caput-index を求める方法であ るが，図1右は，私たちの考案した超音波を使って Caput-index をもとめる方法である.超音波断層像で, 骨端線に沿って直線を引き, 骨頭の頂点よりこの線に 向かって垂線をひく，aをbで割った值をここでは 仮に echo index としておく.

結 果

正常股関節

正常の股関節の超音波断層像を，図 2 に示した．腸 骨，骨端，軟骨性骨頭，limbus，関節包が描出される が，腸骨および骨端は，骨性組織のため音波が強く反 

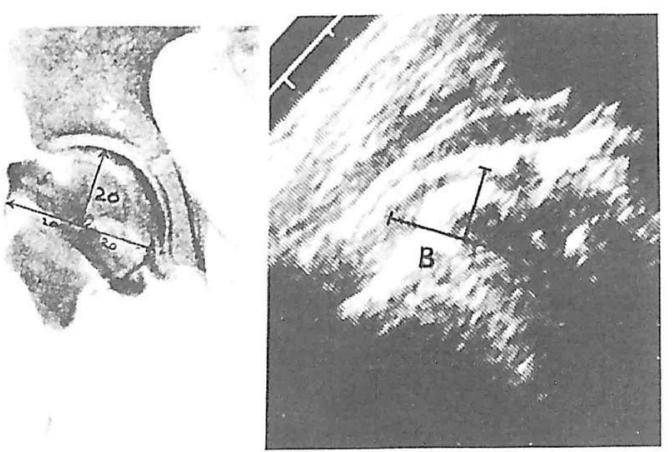

図 $1 \frac{a}{b}$ echoindex
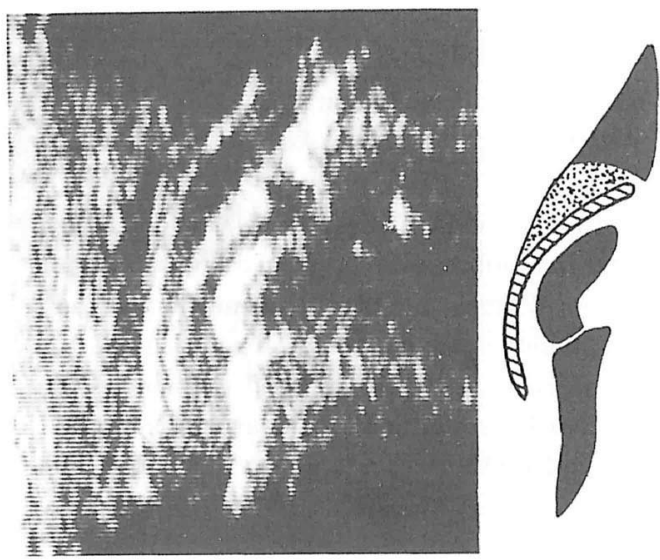

図 2 正常股関節像

射されて screen に懐く写しだされる。軟骨性骨頭表面 およびlimbusは, 淡く描出されるが, 関節を少し動か しながら見てみると,軟骨および limbusはより明確に 判別される. 正常股関節の echo-index は, 100 前後で ある。

症例 $1 ： 5$ 才, 男子.

発症後 1 年の関節造影像である。骨頭は, Coxa Magna になっており, Caput-index は，健側 100，患 側 75 であった。超音波断層像による echo-index でも 健倒 100, 患側 75 となっており, Jonsäter の Caputindex と同じ値となった。

症例 $2: 6$ 才, 男子.

発症後 2 年の股関節造影像を示す. Caput-indexは, 健側 94, 患側 73 であり, echo-index は, それぞれ, 100，82，であった. Coxa Magna を認め，軟骨の偏平 化がみられる。

症例 $3: 11$ 才, 男子.

発症後 3 年の関節造影像による Caput-index は, 健

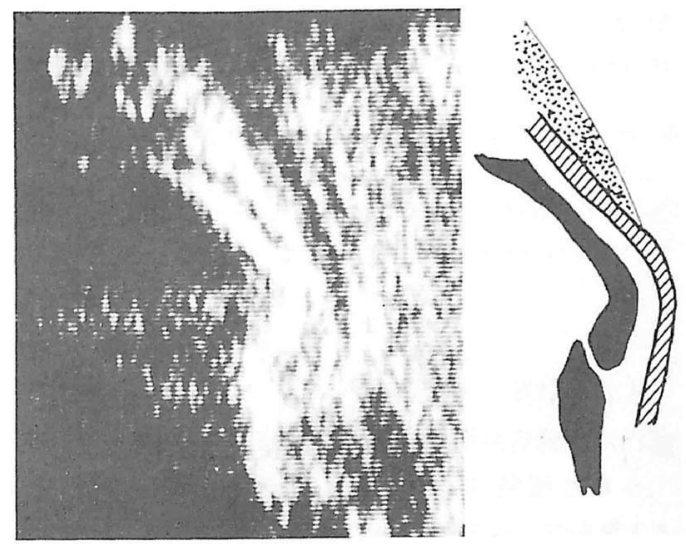

図 3 骨頭偏化像

側 100, 患側 80 である. 骨頭の変形が認められるが, 図 3 に示したように超音波像でも, limbus の先端部付 近での骨頭の偏平化が認められる, echo-indexは, 健 側 100, 患側 88 で, Caput-index とよく一致している. 症例 4:4才, 男子.

発症時から検查を行っている症例である. 最初の超 音波断層像では, 健側とおおきな変化はみられないが, 7 月後には, Coxa magna になっているのが観察さ れた。

ペルテス病の単純レ線から, 骨頭の変形を評価する ために，さまざまな index が用いられている。しかし， いずれも骨性部分のみの計測から軟骨部分を推定して いるため，変形を正しく表現しているのではない．し たがって，軟骨性骨頭の形をもっとも正確に評価する には, Jonsäter の Caput-index をもとめなければなら ない、しかしながら，小児に関節造影をたびたび行う ことは，負担の大きいものである，その点，超音波は レ線のような害がなく, 必要に応じて何回でも検查が できもし変形の正確な評価がなされれば，たいへん 便利なものとなろう.私たちの考案した echo-index は, 関節造影によるCaput-index とほほ一致し, 变形をよ く表現していると考えられるが，今後さらに症例を増 やして検討を加えていきたい.

\section{質 問 九州大学 香月 一明}

超音波診断は骨頭変形の自然経過のみのスクリニン グに使用しているのですか. 手術適応時期の判定につ いては有用なのでしょうか. 
質 問 福岡大学 桜木 孝二 (1) 周波数は $3.5 \mathrm{MHz}$ を用いている.

(1) 周波数は何 $\mathrm{MHz}$ の超音波を打使いか?

(2) 超音波断層像は，ペルテス病の経過を観察する

(2) 超音波検査では，骨頭内側部の変化を見にくい＼cjkstart時,および治療の内容を決定する時に参考にしている. のではないか?

(3) 超音波断層像では骨頭の内側は観察できない。 しかし，一般的にペルテス病の変化は荷重部付近に著

解 答

小倉記念病院 鈴木 茂夫 明なので，外 $2 / 3$ が観察されれば充分と思う。 